\title{
La Grande Peur dans la montagne ou o nascimento de uma lenda
}

Jérôme Berney

As lendas dos Alpes ocupam lugar importante na obra de Ramuz. Elas inspiraram o escritor durante toda a sua carreira, desde as primeiras novelas publicadas em jornal, como La langue de l'abesse. Conte (1904), até sua última coletânea de novelas intitulada Les servants et autres nouvelles (1946), passando por Le village dans la montagne (1908), sem esquecer os romances, em especial La Grande Peur dans la montagne* e Derborence (1936).

Foi durante grandes estadas nas montanhas dos cantões de Vaud e Valai que Ramuz escutou essas histórias, contadas à noite, à beira do fogo, na hora da vigília. Histórias que também pôde ler nas inúmeras coletâneas de lendas, publicadas na época. De fato, no fim do século XIX e início do século XX, um grande número de etnólogos e eruditos se mobilizou para salvaguardar histórias consideradas ameaçadas pelo mundo moderno.

Ao contrário dos "cientistas", Ramuz não procurou coletar de maneira objetiva essas histórias, mas as reescreveu, adaptou-as, transformou-as. As lendas alpinas são material que o escritor moldou de múltiplas maneiras.

Em artigo crítico sobre o livro Contes et légendes de la Suisse hérö̈que (1913), de Gonzague de Reynold, Ramuz evoca a necessidade de renovar as lendas populares:

Os contos que nos contaram, por si só, estão mortos. Foram um ruído que se calou, escaparam de lábios desde então fechados; o que sairá dos nossos lábios, que se abrem? Lá no alto, à noite, quando estão sentados diante do fogo, possivelmente são as mesmas histórias que reaparecem, mas, para cada um que as conta, esse ar
Les contes qu'on nous a contés, par cela seul, sont morts. Ils ont été un petit bruit qui s'est tu, ils se sont envolés de lèvres désormais closes; nos lèvres à nous s'ouvrent, que va-t-il en sortir? Là-haut, quand ils sont assis les soirs d'hiver devant le feu, ce sont bien peut-être les mêmes histoires qui reviennent, mais, à
"(Ramuz, Charles-Ferdinand. La Grande Peur dans la montagne. Paris: Grasset [Le li. vre de Poche], 1926.) 
"(Ramuz, Charles-Ferdi. nand. "Mythes" [ Gazette de Lausanne, 7 de dezembro de 1913]. Em: Critiques littéraires, edição preparada, anota da e prefaciada por J. Meizoz. Genebra: Editions Slatkine 1997: 241-3, grifos meus.)

(Dentan, Michel. La Grande Peur dans la montagne [profi d'une œuvre]. Paris: Hatier e Lausanne: Foma, 1977.)

(:50.)

* Ramuz, Charles-Ferdi nand. "La Grande Peur dans la montagne". CEuvrescom plètes, vol. 13. Lausanne: Mermod, 1941.) imponente de fidelidade não engana. Ele reinventa, redescobre. Opoeta vai ainda mais longe: ele deve inventar e descobrir.* chacun de ceux qui les racontent, ce grand air de fidélité qu'il peut avoir ne trompe pas. Il réinvente, il redécouvre. Le poète va plus loin encore: il doit inventer et découvrir.

Enquanto um estudo sistemático das diferentes maneiras pelas quais um escritor retoma, reinventa ou até mesmo inventa as lendas ainda não existe, proponho-me a estudar essa questão em detalhes no romance La Grande Peur dans la montagne (1926), que valoriza o imaginário alpino.

La Grande Peur dans la montagne conta a destruição de um vilarejo na montanha. Uma pequena comunidade é destruída por uma avalancha de água e lama, provocada pela ruptura de um bolsão de água da geleira. A catástrofe encerra uma série de acontecimentos durante os quais os habitantes do vilarejo são confrontados com uma pastagem "maldita".

Considerado uma das obras-primas de Ramuz, o romance já foi amplamente comentado, em particular por Michel Dentan. Em uma monografia dedicada a La Grande Peur dans la montagne ${ }^{*}$, o crítico mostra, fundamentalmente, a coexistência no seio do texto de dois pontos de vista sobre os fatos, de duas interpretações dos eventos catastróficos. De um lado, a concepção "natural", realista: a série de infortúnios é somente uma sucessão de coincidências, todas racionalmente explicáveis. Do outro lado, uma visão "sobrenatural": a montanha pune os que transgrediram a proibição que pesava sobre a pastagem. Sobre esse assunto, Dentan sublinha que "o que se lê, no romance, não é uma realidade sobrenatural da montanha, mas os medos ancestrais de seus habitantes, as crenças irracionais, um comportamento supersticioso"*.

É precisamente esse aspecto que pretendo desenvolver aqui, mostrando como as "crenças irracionais", as lendas, sustentam La Grande Peur dans la montagne.

É necessário, primeiramente, precisar que existem duas versões de La Grande Peur dans la montagne. Quando incluiu o romance nas CEuvres complèteš, Ramuz fez algumas modificações no texto. Suprimiu sobretudo os quatro últimos parágrafos do romance, conferindo assim uma outra tonalidade ao conjunto. Para minha análise, baseio-me na edição original por duas razões. Primeira, porque se trata 
do texto mais correntemente difundido hoje em dia, tendo sido retomado em duas edições de bolso. Segunda, o desfecho da edição original é muito interessante no que concerne às lendas.

\section{Um esquema lendário}

Mesmo sem o retomar diretamente, o esquema narrativo do romance lembra muito o das lendas. $\mathrm{O}$ resumo dos principais tipos de lendas alpinas, realizado por Lutz Röhrich em "Le monde surnaturel dans les légendes alpines"*, permite perceber que La Grande Peur dans la montagne se aproxima das lendas que explicam a paisagem alpina:

Existe uma série de lendas relativas às origens da paisagem alpina que consideram que ela nem sempre teve o aspecto apresentado hoje em dia. Lá onde agora se estendem a neve, o gelo e fragmentos de rochas, lá onde surgem penhascos abruptos, existiam outrora campos férteis, jardins floridos e prados acolhedores. Sob a forma de variantes constantemente renovadas, conta-se que uma ação impura (profanação do pão, leite, ou outros alimentos, falta de hospitalidade, falta de afeição pelas crianças, etc.) teve por conseqüência a destruição dos campos antes floridos."

Em La Grande Peur dans la montagne, é fácil descobrir que ação profana foi cometida. No início do romance, dois clãs se afrontam por uma pastagem situada na parte alta da montanha; um pasto abandonado vinte anos antes, devido a uma série de infortúnios que se abateram sobre os pastores. O pasto era maldito, segundo os anciãos do vilarejo. Ora, os mais novos já não acreditam "nessas histórias" - o termo lenda nunca é utilizado no romance, mas essas "histórias", termo que aparece inúmeras vezes, são o que se entende por lendas - e decidem explorar novamente o terreno. Os infortúnios se sucedem até a catástrofe final. Um bolsão de água da geleira que domina a cidade cede e a água inunda os pastos, e em seguida o vilarejo abaixo: "sem rastro de grama, sem rastro de casa. Tudo foi recoberto pelas pedras"*. Uma verdadeira punição, como sublinha a última frase do romance: "é que a montanha tem suas próprias idéias, é que a montanha tem suas vontades"*.

Esse resumo evidentemente simplifica o romance, mas serve para pôr em evidência uma das múltiplas tramas de La Grande Peur dans la montagne. Uma trama lendária que
"(Röhrich, Lutz. "Le monde surnaturel dans les légendes alpines", Le monde alpin et rhodanien. Grenoble: Centre alpin et rhodanien logie, 1982: 25-41.)

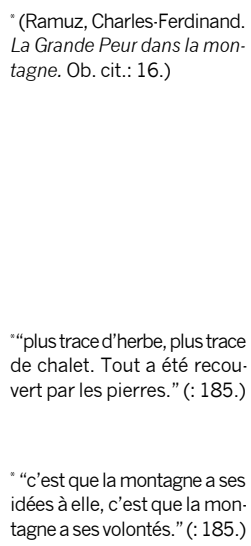

"“plus trace d'herbe, plus trace de chalet. Tout a été recou vert par les pierres." (: 185.)

" "c'est que la montagne a ses idées à elle, c'est que la mon. tagne a ses volontés." (: 185 .) 
(Michelet, Jules. La Montagne. Paris: A. Lacroix, Verbroeckhoven et Cie, 1868: 20.)

(Ramuz, Charles-Ferdinand. La Grande Peur dans la mon tagne. Ob. cit.: 16 , grifos meus.)

participa do ponto de vista dos mais velhos sobre os acontecimentos, o que Dentan chama de perspectiva sobrenatural. Ramuz retoma aqui um lugar comum, que ele revisita e renova, como veremos.

Inúmeras passagens de La Grande Peur dans la montagne podem ser relidas, dessa forma, à luz do corpus lendário.

\section{O “mau país”}

A descrição da primeira subida aos pastos altos, por exemplo, exprime o ponto de vista dos anciãos sobre a montanha. Na topografia imaginária ancestral, existe uma oposição entre o baixo verdejante, que simboliza a vida, e o alto rochoso e gelado, símbolo da morte. Mais precisamente, o alto glacial é comparado a um purgatório infernal, aspecto que será desenvolvido mais adiante. De qualquer forma, o alto é o "mau país", como diz Jules Michelet em La Montagne: "O habitante da montanha não a vê como nós. Ele é muito ligado a ela, e a ela sempre volta, mas a chama de 'mau país"”* Ramuz retoma esse lugar comum ao descrever a primeira subida, da qual segue um trecho:

Quanto a eles, eram cada vez menores lá em cima, sob os penhascos cada vez mais altos, que eram também cinza, um cinza escuro, depois cinza claro; depois, de repente, ficaram rosa, falsamente rosa, porque não é o tipo de cor que dura; é uma cor como a das flores, mas uma cor enganosa, que passa rápido, já que aqui também não existem mais flores, nem nenhuma espécie de vida; e o mau país, que é vil de se ver e que dá medo de se ver, tinha chegado.*
Et eux, ils furent de plus en plus petits là-haut, sous les parois de plus en plus hautes, qui furent grises aussi, d'un gris sombre, puis d'un gris plus clair; puis, tout à coup, elles sont devenues roses, faussement roses, parce que ce n'est pas une couleur qui dure; c'est une couleur comme celle des fleurs, mais une couleur trompeuse, qui passe vite, car il n'y a plus de fleurs ici, non plus, ni aucune espèce de vie; et le mauvais pays était venu qui est vilain à voir et qui fait peur à voir.*

Enquanto essa primeira subida ao pasto serve como mau presságio, a segunda não é de forma alguma apresentada da mesma maneira. No capítulo IV, toda a comunidade acompanha os sete pastores que vão ali passar o verão inteiro. A descrição da subida é, agora, positiva: 
Eles fizeram esse longo caminho, esse longo caminho da montanha; primeiro, na relva cheia de flores por todos os lados como grandes manchas, depois entre os pinheiros, sobre um tapete de agulhas também manchado com manchas redondas e bordado em ouro - os campos, a floresta, o sol, o sol e a sombra; depois a enorme garganta e depois nada além de sombra; depois começa o pedregulho, desmoronamentos, e então o sol novamente $[\ldots]$. ${ }^{*}$
Ils ont fait tout ce long chemin, ce long chemin de la montagne; d'abord, dans l'herbe pleine de fleurs de tout côté par grosses taches, puis entre les sapins, sur le tapis des aiguilles tout taché lui aussi de taches rondes et brodé d'or - les prés, la forêt, le soleil, le soleil et l'ombre; puis la grande gorge et puis plus rien que l'ombre; puis la rocaille qui commence, les éboulis, alors le soleil de nouveau $[\ldots]$. ${ }^{*}$

Reunidos e levados pelo jovem prefeito, os habitantes do vilarejo não receiam o alto da montanha. Somente quando estiverem abandonados à própria (má) sorte é que os sete pastores se sentirão novamente ameaçados.

Durante todo o romance, Ramuz alterna e confronta dessa forma diferentes percepções sobre a montanha, ora povoada por espíritos do mal, dos quais os velhos desconfiam, ora simples natureza generosa, que o clã dos jovens deseja explorar.

\section{O caçador diabólico}

O personagem de Clou se liga a um outro topos lendário. $\mathrm{O}$ prefeito o empregou contra a sua vontade para fazer parte dos sete pastores que deveriam passar o verão lá no alto. Trata-se de um ser estranho, marginal, cuja aparência e atividades apavoram os habitantes:

Ele olhava o prefeito com seu único olho, o direito; não era nunca possível saber muito bem se ele de fato estava olhando ou não.

Nunca dava para ter certeza com ele, de forma que o prefeito se via sem saída, não tendo conseguido empregar ninguém, por um lado, mas porque gostaria, por outro lado, de não ter preci-
Il regardait le Président avec son seul oeil, qui était le droit; on ne savait jamais très bien s'il vous regardait ou non.

On ne savait jamais très bien avec lui, de sorte que le Président se trouva embarrassé, n'ayant réussi encore à engager personne d'une part, mais parce qu'il aurait beaucoup mieux aimé, d'autre part, s'il 
sado chamar um tipo de homem como aquele, que ninguém desejava há tempos; enquanto isso ele vivia sabe-se lá de quê, caçando sem licença, pescando sem licença, colhendo plantas na montanha, catando pedras, e parece que ouro também; enquanto outras coisas só eram ditas em voz baixa.*
"(:20.)

(De Saussure, Horace Bénédict. Premières ascensions au Mont-Blanc 1772. 1787. Paris: François Mas. péro [La Découverte], 1979: 117.)

“Lui, l'Autre, le Méchant". (Ramuz, Charles-Ferdinand. La Grande Peur dans la montagne. Ob. cit.: 154 .) l'avait pu, ne pas avoir affaire à cette espèce d'hommes-là; à un homme de cette espèce, dont plus personne ne voulait depuis longtemps; alors il vivait, on ne savait pas très bien de quoi, allant chasser sans permis, allant pêcher sans permis, allant chercher des plantes dans la montagne, allant chercher des pierres, et on disait de l'or aussi; tandis que, certaines autres choses, on ne se les disait qu'à l'oreille.*

O corpus das lendas alpinas está repleto desses caçadores ilegais e contrabandistas de ouro, de aparência inquietante, que se tornam feiticeiros por freqüentarem a parte alta da montanha e pelos encontros estranhos que têm por lá. $\mathrm{O}$ caçador vai e vem entre os mundos natural e sobrenatural. O cabrito montês que ele persegue se revela às vezes uma fada, ou uma bruxa. O ouro que procura no fundo das fendas ou grutas é muitas vezes guardado por diabinhos. Lutz Röhrich distingue ao menos três tipos de lendas de caçadores entre as principais lendas alpinas.

Em outro registro, vejamos como Horace-Bénédict de Saussure, o célebre alpinista e cientista genovês, entendia as crenças em torno dos caçadores:

O pequeno número de pessoas que envelhecem nessa profissão carrega na fisionomia a marca da vida que levaram; um ar selvagem, um que de perdido e assustado que se reconhece em meio a uma multidão, mesmo quando não estão vestindo seus trajes. Talvez seja essa fisionomia que faça crer a alguns camponeses supersticiosos que eles são feiticeiros, que na sua solidão têm trato com o diabo, e que na verdade é o próprio diabo que os joga no precipício."

Clou parece efetivamente ter "trato com o diabo", com "Ele, o Outro, o Malvado"*. Marginal em relação aos seis outros pastores, ronda pela montanha dia e noite, à procura de ouro e pedras preciosas. As doenças e a loucura que vão afetando progressivamente o pequeno grupo não o atingem. Ele nada teme e, com seu olho doente, assiste zombando à deterioração dos companheiros.

Esse personagem típico das lendas, que Ramuz retoma e enriquece, participa da veia sobrenatural do romance. Para 
o leitor, ele serve como um sinal de que eventos estranhos se apresentarão.

\section{O purgatório glacial}

Clou se sente especialmente à vontade na geleira e em seus acessos rochosos. Ora, no imaginário da montanha, a geleira é um lugar muito particular. Ela representa o purgatório, esse lugar intermediário onde as almas dos mortos cumprem penitência. No artigo "Un purgatoire alpin (Loetschental)"*, Claude Macherel mostra o quanto a situação topográfica da geleira, intermediária entre o vale e o céu, assim como seu clima severo, faz dela um purgatório ideal! Se os sicilianos o situaram sobre o Etna*, as populações alpinas escolheram as geleiras, cujo vento gelado nada deixa a desejar ao calor infernal dos vulcões. Notemos ainda que o purgatório glacial faz parte dos purgatórios infernais, contrariamente a outros purgatórios mais próximos do paraíso ${ }^{1}$.

Um grande número de lendas evoca os desertos gelados onde erram as almas dos condenados. Os vivos que lá se aventuram têm encontros dos quais nunca saem ilesos. Sem ser totalmente explícita, a geleira como purgatório está presente em La Grande Peur dans la montagne. Ramuz conhecia muito bem o tema, já que o havia explorado em vários textos antes de escrever esse romance. As almas da geleira aparecem no último capítulo de Le village dans la montagne*, na novela de 1913, Les âmes dans le glacier, e em La Guerre dans le Haut-Pays (1915)*. Em La Grande Peur dans la montagne, Ramuz retoma o tema, desta vez de maneira implícita, utilizando imagens, metáforas e expressões que pertencem a esse lugar comum lendário.

Na primeira vez em que é descrita, a geleira parece inofensiva. Depois da rigorosa subida para chegar ao "mau país", a geleira se afigura acolhedora:

E, ao fundo da pastagem, aparecia também a geleira, pintada de belas cores assim como o vale
Et, dans le fond du pâturage, venait aussi le glacier qui pendait là, peint en belles couleurs de

\begin{abstract}
"(Macherel, C. "Un Purga. toire alpin [Loetschental]", Le Monde alpin et rhodanien. La haute montagne. Vision et représentation ne. Vision et représentation, n. 1-2. Greno ble: Centre alpin et rhoda-
nien d'ethnologie, 1988: 87 . 112.) Cf. Também o artigo de R.C. Schüle, "'il vaut mieux souffrir du froid main. tenant...'. Le purgatoire dans les glaciers", Imaginaires de la haute montagne. res de la haute montagne. Grenoble: Centre alpin et rhodanien d'ethnologie, 1987:31-40.)

" (Sobre o assunto, ver Le Goff, Jacques. La naissance du purgatoire. Paris: Gallimard, 1981.)
\end{abstract} "(Ramuz, Charles-Ferdinand.
"Le village dans la monta-
gne". CEuvres complètes, vol.
3. Ob. cit.: 296-7.)
"Ramuz, Charles-Ferdinand.
CEuvres complètes, vol. 7. Ob.
cit.: 133.)

\footnotetext{
${ }^{1}$ Como sublinha Jacques Le Goff, a imprecisão dos textos religiosos sobre o tema - a Bíblia nem toca no assunto - deixou grande liberdade de invenção às diferentes comunidades católicas, que então imaginaram todos os tipos possíveis de purgatório.
} 
(Ramuz, Charles-Ferdinand La Grande Peur dans la mon tagne. Ob. cit: 17 .

"Il parut venir à votre ren contre avec une couleur méchante, une vilaine cou leur pâle et verte [...]." (: 40.)

“comme les réprouvés qui n'ont plus permission de se mêler aux autres hommes ou seulement de s'appro. cher d'eux." (: 139.)

*(: 131 e 153.)

"(Röhrich, Lutz. "Le monde surnaturel dans les légendes alpines ". Ob. cit.: 29.) todo; e essas lindas cores todas vinham em sua direção; mas eles quase não percebiam, outra coisa os interessava.* même que toute la combe; et ces belles couleurs toutes ensembles leur venaient contre; mais c'est à peine s'ils y ont fait attention, c'est autre chose qui les intéressait. ${ }^{*}$

A segunda aparição da geleira é diferente. Desta vez, é a geleira pesada de ameaças que domina a pastagem. A descrição intervém no momento em que os sete pastores se encontram sozinhos pela primeira vez. Os habitantes que os haviam acompanhado tinham acabado de descer. Enquanto essa segunda subida à parte alta é tranqüila, como já foi dito, a geleira em si mesma parece assustadora: "Pareceu vir a nosso encontro com uma cor má, uma cor feia, pálida e verde [...]”*. É a cor dos mortos-vivos, a cor das almas errantes.

Ao longo do romance, a geleira terá cada vez mais espaço e importância. O purgatório glacial se apropria progressivamente da pastagem. Os pastores que vivem logo abaixo da geleira serão de alguma forma capturados pelo mundo dos condenados que os domina. Depois dos primeiros alertas - o pequeno Ernest, por demais aterrorizado, foge e adoece (capítulo V), uma mula cai no precipício (capítulo VI)-, a "doença" contamina o rebanho do pasto e retira dos pastores o contato com o mundo de baixo. Postos em quarentena (capítulo VIII), ficam "como rejeitados que não têm permissão de se misturar com os outros homens ou até mesmo deles se aproximar"*. Rejeitados que muito se assemelham aos condenados das lendas.

\section{As almas errantes}

Aos olhos do imaginário alpino, os pastores cometeram um pecado que condenou seres a vagarem pelas geleiras. Para aliviar as vacas das quais ninguém se havia ocupado por muitos dias, o velho Barthélémy as ordenhou, derramando leite na terra. Uma "vergonha", um desperdício terrível para os habitantes cuja economia se baseia em grande parte no leite, e uma profanação, no sentido religioso, já que, como sublinha Lutz Röhrich, "é principalmente o leite derramado [...] que é citado como a razão pela qual as almas pecadoras e errantes [são punidas]"*.

Os pastores "vão caindo" um depois do outro: depois de Ernest, doente, e Romain, ferido, o mestre e seu sobrinho 
desistem de viver, deixando de falar e de se movimentar (capítulo XIV). No fim do capítulo XV, eles já são até comparados a "mortos". Só resistem ainda o velho Barthélemy, protegido por um "documento" santo, o diabólico Clou e Joseph, o jovem noivo.

No início do capítulo XIII - o romance possui 16 - Joseph tem um surto de energia. Com o intuito de reencontrar sua noiva, tenta retornar ao vilarejo. Para evitar as barragens, é obrigado a passar pelas partes mais altas e sobretudo a atravessar a geleira. Uma espécie de subida ao inferno.

Joseph percorre uma primeira vez a geleira, atravessa o desfiladeiro, chega ao vilarejo e descobre sua noiva morta (capítulo XIII). Decide então subir de novo aos altos pastos e atravessa mais um vez a montanha e a geleira (capítulo XV). Inicia, pois, uma segunda travessia, sobre a qual me deterei, pois ela contém numerosas alusões ao purgatório glacial.

Assim que Joseph chega à região das primeiras neves, o dia começa a nascer e um nevoeiro intenso reina nas alturas. $\mathrm{O}$ jovem terá então encontros surpreendentes. $\mathrm{O}$ vocabulário empregado para descrever seu périplo na verdade sugere que a geleira é mal-assombrada. O texto descreve insistentemente os "vapores" que dominam o espaço e nos quais Joseph mergulha. Ora, o termo "vapores" constitui uma das expressões típicas que designam as almas errantes das geleiras. É possível encontrá-lo, por exemplo, em La nuit des quatre-temps, peça de René Morax que se inspira na temática do purgatório glacial: "Vapores brancos pairam sobre a geleira e se dissipam. Quem me chama?”* Quando os vapores se fazem notar, é que são almas errantes².

Mergulhado nos vapores e na escuridão da geleira, Joseph pensa na noiva morta:

E o barulho que se ouviu então não vinha da geleira, veio da direita de Joseph e das escarpas mais altas, de onde pedras desci-
Et le bruit qu'il y a eu enfin, n'est pas venu du glacier, il s'est fait entendre à la droite de Joseph et plus haut dans l'escarpement,

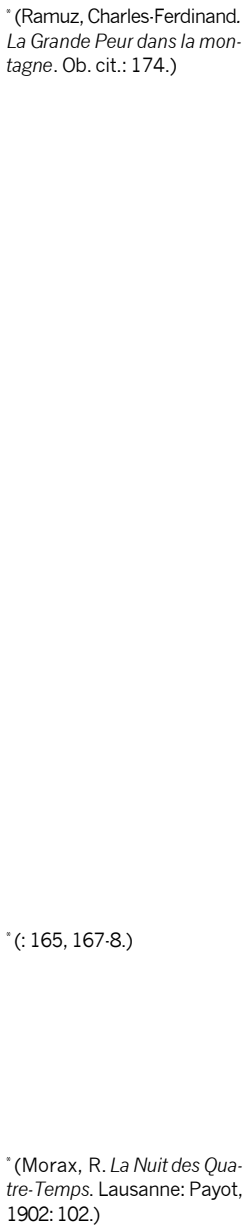

"(Morax, R. La Nuit des Qua. tre-Temps. Lausanne: Payot, 1902: 102.)

\footnotetext{
${ }^{2}$ Como outro exemplo, cito trecho de uma lenda em que as almas condenadas aparecem sob a forma de vapores: "Um jovem pastor tomava conta de suas cabras na pastagem de Garboula, acima de Saint-Luc. Numa manhã, viu pequenos vapores brancos, com formas humanas, andando em procissão em torno do campo; havia milhares deles". Récits, contes et légendes du Val d'Anniviers. Sierre: Editions à la Carte, 1998: 131.
} 
(Ramuz, Charles-Ferdinand. La Grande Peur dans la mon. tagne. Ob. cit.: 165 , grifos meus.)

(Macherel, C. "Un purga toire alpin [Loetschental]" Ob. cit.: 91-3.) am rolando até ele, pelo menos era o que lhe parecia, já que também não se podia ver nada daquele lado. E naquela hora ela ainda estava na cama; era a única coisa que ainda podia ver: lá na cama, com as duas velas, o pires cheio de água, um galhinho de pinheiro mergulhado na água do pires $[\ldots]$.* d'où des pierres sont descendues en roulant jusqu'à lui, du moins c'est ce qu'il lui a semblé, parce qu'on ne pouvait toujours rien voir, de ce côté-là non plus. Et dans le même moment elle a été encore sur le lit; c'est la seule chose qu'il voyait encore: sur son lit de là-bas, avec les deux bougies, la soucoupe pleine d'eau, une branchette de mélèze trempant dans l'eau de la soucoupe $[\ldots]$.**

O parágrafo seguinte descreve novamente os vapores que envolvem o personagem:

Percebe que os vapores que pai- Il voit que les vapeurs qui penravam como cortinas em torno dele se levantam; que começam a se desfazer, movimentam-se, enquanto ele próprio continuava a descer; os vapores se desfiavam.* $^{*}$

daient tout autour de lui comme des rideaux se soulèvent; il voit qu'elles commencent à se défaire, elles bougent, pendant que luimême continuait à descendre; elles s'effrangent.*

A alma de Victorine, a noiva, erraria já em meio aos vapores moventes da geleira? ${ }^{3}$

Mais adiante, Ramuz utiliza uma outra expressão empregada habitualmente em relação às almas errantes. Entre os barulhos misteriosos da montanha, Joseph ouve rolarem as pedras. Elas vêm "em grandes bandos"*

Ora é mesmo "em grandes bandos" que se deslocam nas lendas os condenados do purgatório. Evoca-se freqüentemente, por exemplo, o "bando dos mortos"*.

De repente, uma voz se mistura ao barulho das pedras, e uma silhueta se separa dos vapores. Clou parece surgir do reino dos espíritos:

\footnotetext{
${ }^{3}$ No imaginário da montanha, seria muito plausível que Victorine se encontrasse no purgatório, pois ela transgrediu a proibição ao ultrapassar a barreira que separava os habitantes do vilarejo dos pastores, ato que pode ser considerado um pecado, uma vez que punha em perigo toda a comunidade.
} 
São ainda as pedras que rolam ou é a montanha que tem voz? [...].

Vinha lá do alto dos rochedos, na linha dos vapores; teve a impressão de que os vapores se abriam à frente como o batente de uma porta.

Joseph vê lá em cima o nevoeiro que se desfaz; pela abertura, um homem vem à frente [...].*
Est-ce encore les pierres qui roulent ou si c'est la montagne elle-même qui a une voix $[\ldots]$.

C'était là-haut dans les rochers, à la limite des vapeurs; il a cru voir qu'elles se fendaient et allaient en avant comme le battant d'une porte.

Joseph voit là-haut le brouillard se fendre; par l'ouverture, un homme se porte en avant $[\ldots]$.
"(Ramuz, Charles-Ferdinand. La Grande Peur dans la montagne. Ob. cit.: 168 .)

A seguir, Clou e sua risada diabólica começam a perseguir Joseph, que se desespera e atira em Clou. A bala atravessa em vão o seu corpo. Clou seria uma alma? De qualquer modo, ele é comparado a um "farrapo de vapor": "Mas a bala passa através do outro que se aproxima, como se fosse nevoeiro, como se fosse um farrapo desses vapores lá do alto; ela atinge a geleira, que se parte."*

\section{Loucura, fantasma, sonho: percepções em xeque}

O modo como ele utiliza e destila os elementos recorrentes é reveladora. Os topoi lendários participam da ambigüidade geral que envolve os eventos. Quando eles sustentam uma interpretação, uma visão do mundo, isso se faz sempre de forma implícita, deixando espaço para a dúvida. Os "vapores" e os "bandos" da geleira não são apresentados explicitamente como almas errantes, mas sugeridos. São indícios, não provas, que tecem tramas interpretativas do romance ${ }^{4}$.

A incerteza está no centro do romance. Mesmo que o medo e o ponto de vista dos velhos ganhem espaço à medida que a narrativa progride, a dúvida sobre a interpretação dos fatos subsiste até o fim. Uma interpretação "natural" permanece possível, já que, afinal, a doença que atinge o rebanho é comum, e a catástrofe pode ser explicada racionalmente: "Deve ter se formado uma barragem na geleira"*.

\footnotetext{
" "Il avait dû se former un barrage dans le glacier." (Ra. muz, Charles-Ferdinand. La Grande Peur dans la monta. gne. Ob. cit.: 184.)
}

vers celui qui vient, comme si c'était du brouillard, comme si c'était un lam. beau de ces vapeurs là-haut elle va frapper le glacier qui craque." (: 170 , grifos meus.) ção bíblica. Inúmeras alusões ao $\hat{E} x o d o$ se espalham pelo romance, costurando mais uma rede interpretativa. 
" "Peut-être qu'on rêvait avant et on rêve encore à présent" (: 166.).

"(Millet, Claude. Le légen daire au XIXe siècle. Poésie, mythe et vérité. Paris: PUF, 1997.)

As "visões" de Joseph na geleira e principalmente a aparição de Clou são constantemente postas em dúvida pela própria narração. Por exemplo, quando o narrador acredita estar vendo a geleira se mexer, ele insiste - ou seria o próprio personagem? - que seria o cansaço:

Era o que ele ainda conseguia entrever, enquanto mal respirava; e a parte inferior da geleira começa então a se iluminar em verde e azul, chegando até ele com seus reflexos verdes e azuis, como uma dupla iluminação, ao mesmo tempo em que a geleira subia, e descia, depois subia novamente. É preciso dizer que não se dormia há dois dias.*
C'est ce qu'il aperçoit encore, tandis qu'il respirait mal; et d'en bas le glacier a commencé alors à éclairer en vert et en bleu, venant à lui avec ses reflets verts et bleus, dans un double éclairage, en même temps que le glacier montait, il redescendait, puis remontait. Il faut dire qu'on n'a pas dormi depuis deux jours."

Não foi somente o cansaço, mas também a escuridão, o nevoeiro e a tristeza que fragilizaram Joseph, possível vítima de alucinações. Tudo pode às vezes parecer falso, e Joseph chega mesmo a se perguntar se estaria sonhando: "Talvez sonhássemos antes, e continuemos a sonhar agora"* .

No livro Le légendaire au XIXe siècle ${ }^{*}$, Claude Millet repertoria a utilização das lendas entre escritores e historiadores franceses durante o século XIX ${ }^{5}$. Percebe assim uma evolução ao longo do século, útil à minha proposta, que resumo aqui de forma sucinta. A autora opõe os românticos do início do século, Charles Nodier e Prosper Mérimée, entre outros, aos realistas, ou naturalistas, do fim do século XIX, como Maupassant e Zola. Para os primeiros, as lendas permitiam que se constituísse um elo comunitário em torno de uma origem mítica. O maravilhoso se inscreve na perspectiva política e religiosa. Em compensação, para os últimos, a relação com o lendário é bem mais individual. A lenda se torna simplesmente o sobrenatural com o qual se deve confrontar o personagem, cujo psiquismo é posto a dura prova. No intervalo entre essas duas concepções, dá-se o que Claude

${ }^{5}$ Trata-se da obra mais geral sobre o assunto, de que tenho conhecimento. Infelizmente para o nosso tema, o livro não se refere ao século XX, no entanto, os escritores do fim do século XIX, cuja leitura formou Ramuz, fornecem um bom ponto de comparação com o escritor. 
Millet chamou de um "desligamento coletivo". Os laços lendários que soldavam as comunidades se desintegram aos poucos, principalmente sob a pressão do progresso. La Grande Peur dans la montagne põe em cena exatamente esse "desligamento coletivo". As crenças nas "velhas histórias” já não são mais partilhadas por todos. O clã dos jovens já não quer mais ouvir falar da maldição da pastagem. A comunidade se divide então em dois clãs. A obsessão ramuziana de separação entre os seres encontra, nesse contexto, uma nova forma ${ }^{6}$.

Os apontamentos de Claude Millet sobre Maupassant e Zola podem ajudar a precisar a relação entre Ramuz e o lendário, como nessa conclusão a que a autora chega:

O lendário deixa de ser a criação de um sujeito, que, ao mesmo tempo singular e universal, realiza o canto da própria comunidade. Ele é a construção de um imaginário individual, que se serve de lendas e mitos do passado como matéria-prima. E esse imaginário individual não pertence ao escritor, mas ao personagem. $\mathrm{O}$ que se conta não é a lenda, mas a história da relação com a lenda, é a história da eficácia da lenda no destino de um personagem, na construção de seu imaginário com base em um material lendário. Loucura, fantasma, sonho: o lendário tornado íntimo."

De forma geral, essas conclusões se aplicam muito bem a $L a$ Grande Peur dans la montagne. Primeiramente, fica claro que as lendas são matéria-prima para Ramuz. O escritor colhe no corpus lendário símbolos, fragmentos de histórias, todo um imaginário com o qual confronta os personagens. O que interessa é a relação com a lenda, e não a própria lenda. Uma relação com a lenda que divide a comunidade em dois clãs, já que, de um lado, os anciãos acreditam ainda "naquelas histórias" e, do outro, os jovens não acreditam mais. Além disso, a exploração da loucura, do fantasma e do sonho parece perfeitamente ilustrada pelo personagem de Joseph, principalmente no momento da travessia da geleira.

Em uma análise mais precisa, todavia, Ramuz não se assemelha tanto a Maupassant ou a Zola. É interessante, por

${ }^{6}$ A problemática da separação é central em vários romances de Ramuz, anteriores a La Grande Peur dans la montagne. Tomemos por exemplo La Séparation des races (1923), no qual duas comunidades de língua e religião diferentes estão separadas por uma montanha, ou Passage du poète (1923), que evoca seres solitários, separados uns dos outros, e finalmente reunidos graças à passagem de um artesão, figura do poeta.
(Millet, Claude. Le légen daire au XIXe siècle. Ob. cit. 255.) 
"(Le Horla et autres contes d'angoisse. Paris: Flamma rion, 1984.) exemplo, confrontar La Grande Peur dans la montagne com alguns textos de Maupassant, marcados pelas lendas ${ }^{7}$. Claude Millet, no artigo "Le légendaire dans l'œuvre de Maupassant", distingue dois tipos de lendário nos textos do escritor normando.

No primeiro deles, as lendas são crenças populares de que o narrador zomba, como cidadão culto e positivista. $\mathrm{O}$ lendário é visto à distância, como um discurso obsoleto. La légende du Mont Saint-Michel (1882) ironiza o modo de ser dos camponeses normandos, do qual a lenda é uma das expressões mais pitorescas, enquanto Mont-Oriol (1887) desdenha dos charlatães que exploram a credulidade do povo e sua crença nas lendas.

Em Ramuz, de maneira geral e em particular em $L a$ Grande Peur dans la montagne, não se notam o distanciamento e a ironia com relação às lendas e àqueles que nelas crêem. $\mathrm{O}$ escritor não julga, mas confronta diferentes visões e percepções do mundo. Na verdade, as lendas alpinas não representam o pitoresco ${ }^{8}$ ou a credulidade dos habitantes da montanha, mas exprimem uma das numerosas vozes, a voz dos mais velhos, que participam da narração ${ }^{9}$. O segundo tipo de lendário levantado por Claude Millet na obra de Maupassant parece mais próximo do que encontramos em Ramuz. O lendário dá conta, desta feita, de tudo o que resiste à análise psicológica, abalando as certezas. Em Le Horla $(1886)^{*}$, por exemplo, a lenda do Mont Saint-Michel contada por um velho monge ao narrador é um momento chave da narrativa. A lenda reforça a idéia de que pode haver seres invisíveis, como o demônio que persegue o narrador e destrói sua vida. A dúvida é permitida porque as percepções são enganosas. $\mathrm{Na}$ discussão entre o monge e o narrador que se segue à

Deve-se lembrar que Ramuz conhecia muito bem a obra de Maupassant. Ele havia inclusive participado da edição das CEuvres complètes do escritor no início do século XX. Uma boa comparação entre Ramuz e Maupassant se encontra no artigo de Vincent Verselle, "Pierrot n'amasse pas Mousse ou quand Maupassant et Ramuz maltraitent un chien”, Actes du colloque sur la nouvelle francophone en Belgique et en Suisse, no prelo.

${ }^{8}$ Em artigo intitulado "La beauté de la montagne", publicado na revista Aujourd'hui e datado de 11 de setembro de 1930, Ramuz procura, aliás, distanciarse do pitoresco.

${ }^{9}$ Sobre a grande quantidade de vozes narrativas em La Grande Peur dans la montagne, ver sobretudo a parte "Variations du point de vue", em Michel Dentan. La Grande Peur dans la montagne [profil d'une œuvre]. Ob. cit.: 46-8. 
narrativa da lenda, um paralelo interessante é feito entre esses seres invisíveis e o vento:

\begin{abstract}
Disse ao monge: “Acredita nisso?”
Ele murmurou: "Não sei."

Continuei: "Se existissem na terra outros seres além de nós, como já não os conheceríamos há mais tempo; como você não os teria visto ainda? Como eu não os teria visto ainda?”
\end{abstract}

Ele respondeu: "Não seria por que vemos apenas um milésimo do que existe? Por exemplo, o vento, que é a maior força da natureza, que derruba os homens, abate os edifícios, desenraiza as árvores, transforma o mar em montanhas de água, destrói as falésias, e joga os navios nos recifes, o vento que mata, que assobia, que geme, que muge - já o viu, e é possível vê-lo? No entanto, ele existe."

Calei-me diante do simples raciocínio. Aquele homem era um sábio ou talvez um tolo. Não poderia afirmar com certeza; mas calei-me. Já havia pensado daquela forma.*
Je dis au moine: "Y croyez-vous?”

Il murmura: "Je ne sais pas".

Je repris: "S’il existait sur la terre d'autres êtres que nous, comment ne les connaîtrions-nous point depuis longtemps; comment ne les auriez-vous pas vus, vous? comment ne les aurais-je pas vus, moi?"

Il répondit: "Est-ce que nous voyons la cent millième partie de ce qui existe? Tenez, voici le vent, qui est la plus grande force de la nature, qui renverse les hommes, abat les édifices, déracine les arbres, soulève la mer en montagnes d'eau, détruit les falaises, et jette aux brisants les grands navires, le vent qui tue, qui siffle, qui gémit, qui mugit, - l'avez-vous vu, et pouvez-vous le voir? Il existe pourtant."

Je me tus devant ce simple raisonnement. Cet homme était un sage ou peut-être un sot. Je ne l'aurais pas pu affirmer au juste; mais je me tus. Ce qu'il disait là, je l'avais pensé souvent.*

*(: 58-59.)

No centro do gênero fantástico, do qual Maupassant é uma das figuras de proa, encontra-se justamente a dúvida, a hesitação, a ambigüidade. No fim de Horla, não é possível saber se o narrador foi tomado pela loucura ou "realmente" assombrado por demônios. Ao longo da novela, as percepções do personagem-narrador são postas em dúvida. A lenda do Mont Saint-Michel vem somente sublinhar a possibilidade do sobrenatural.

A problemática da percepção é igualmente central em $L a$ Grande Peur dans la montagne, o que já foi visto em relação à aparição de Clou. Quando Joseph atira nele e as balas o atravessam, a questão que se revela é a seguinte: trata-se de uma 
"Joseph se passe la main sur les trous des yeux qui servent à voir et à connaître, mais peuvent mentir ou se tromper [...]." (Ramuz, Char les.Ferdinand. La Grande Peur dans la montagne. Ob. cit: 144.)

"(: 144.)

" "Ce n'est plus elle; on me l'a changée." (: 146)

(Millet, Claude. "Le légen daire dans l'œuvre de Mau passant", Etudes normandes. Maupassant du réel au fantas tique, n. 2, 1994: 88.) alucinação de Joseph ou o diabólico Clou possui poderes sobrenaturais? O que se sabe é que a vista de Joseph estava perturbada pelo cansaço, pelo nevoeiro e pela emoção.

As aparências enganadoras, a miragem e os simulacros atravessam todo o romance. Nessa perspectiva, o paroxismo parece ser atingido quando Joseph descobre que sua noiva está morta. Não podendo acreditar, duvida de sua percepção visual: "Joseph passa a mão no buraco dos olhos, que servem para ver e conhecer, mas podem mentir ou se enganar [...]”*. A luz das velas faz com que Victorine "falsamente" se mexa. Então, concluirá "Não é mais ela; transformaram-na”". A dúvida quanto às percepções e às certezas leva os personagens em direção ao desconhecido. O lendário, sublinha Claude Millet, permite a exploração das "profundezas obscuras [do] psiquismo". As lendas levam a ultrapassar "as claras certezas da psicologia [...], para se dar conta de uma psicologia de fantasmas, e fantasmas dos mais inquietantes"*.

Em La Grande Peur dans la montagne, a travessia da montanha e da geleira por Joseph, no capítulo XV, faz-se dessa forma. Ramuz emprega o tema lendário do purgatório glacial, renovando-o completamente. Retoma a noção de espaço intermediário entre o aqui e o além, reutiliza certas expressões, os "vapores", os "bandos", para sugerir almas errantes, mas desenvolve e desloca o simbólico e o contexto da geleira. Enquanto as lendas das almas da geleira se situam claramente na perspectiva religiosa e política de ordem comunitária os que pecaram, desperdiçando leite, passam por sofrimentos atrozes -, a geleira de La Grande Peur dans la montagne é um mergulho individual no universo onírico, fantástico, fantasmático $^{10}$. É possível, de fato, considerar essa travessia como uma experiência-limite que conduz Joseph às portas da morte, em uma zona nebulosa, fronteira entre a vida e a morte.

Retomemos mais uma vez o trajeto de Joseph no capítulo XV. Assombrado pela imagem de Victorine, cujo corpo inanimado ele acaba de deixar, ele sobe novamente à pastagem. A noite, o nevoeiro e o cansaço o fazem entrar em uma espécie de transe hipnótico, como se sonhasse acordado. Joseph se di-

${ }^{10} \mathrm{O}$ termo me parece justificado uma vez que foi justamente o desejo que levou à morte Victorine e Joseph. Os dois jovens, um após o outro, não respeitaram a proibição que separava a pastagem do vilarejo. O desejo amoroso individual fez, então, com que transgridissem um limite fixado pela comunidade. 
vide em dois: seu espírito está com Victorine, seu corpo segue maquinalmente o caminho da montanha. "Ele era dois homens, ele foi dois homens"*, sublinha o narrador. É ela mas não é mais ela. Ela está lá embaixo, ela está aqui. O mundo está invertido: o céu está "como terra amarela, como uma grande planície de argila vista ao contrário"*. Nesse espaço intermediário, Joseph se aproxima progressivamente da morte de Victorine. Está cada vez menos aqui, cada vez mais lá. As "águas paradas" da geleira começam a balançar, o gelo parte, e então Clou ("se realmente era Clou”) persegue Joseph. Em um último sobressalto ele atira em Clou. A bala atinge a geleira, a montanha entra em movimento e Joseph "cai para trás"*

Depois da inversão e da mistura entre alto e baixo, aqui e lá, presença e ausência, água parada e água em movimento, vida e morte, Joseph cai definitivamente em um mundo invertido. $\mathrm{O}$ mundo das almas errantes?

\section{Um final envolto em mistério}

O mistério paira sobre o destino de Joseph até o fim. Enquanto a maioria dos habitantes e pastores está morta, Joseph e Clou desapareceram:

[...] Todos os animais passaram por lá. Depois, foi a vez dos homens.

Perguntam: E Joseph?

- Nunca mais foi visto.

Perguntam: E Clou?

- Nunca mais se ouviu falar dele.

- E o dono do chalé?

- Morto. Levou duas balas.

- Seu sobrinho?

- Morto.

- Barthélemy?

- Morto.

- E aquele da mula?

- Morto... Morto de gangrena.

- O pequeno Ernest?

- Morto também.

- O prefeito?

- Morto.

- Compondu?

-Morto.*
Toutes les bêtes y ont passé. Puis les hommes ont eu leur tour.

On dit: Et Joseph?

- On ne l'a jamais revu.

On dit: Et Clou?

- On n'a plus entendu parler de lui.

- Et le maître du chalet?

- Mort. Il avait reçu deux balles.

- Son neveu?

- Mort.

- Barthélemy?

- Mort.

- Et celui du mulet?

- Mort... Mort de la gangrène.

- Le petit Ernest?

- Mort aussi.

- Le Président?

- Mort.

- Compondu?

- Mort."
" "Il était deux hommes, il a été deux hommes" (Ramuz, Charles-Ferdinand. La Grande Peur dans la montagne. Ob. cit.: 164.)

" "comme de la terre jaune, comme une grande plaine d'argile vue à l'envers" (: 166 7).

"(: 170.) 
"(Ramuz, Charles-Ferdinand. La Grande Peur dans la mon tagne. Ob. cit.: 184-5.)
Os dois desaparecidos fazem crescer a fatia de mistério que envolve a catástrofe. Nem mortos, nem vivos, talvez mortosvivos, condenados a assombrar ad aeternum o país alto?

Na edição das CEuvres complètes de 1941, o texto termina por essa enumeração de mortos. Um final abrupto que dá à morte a última palavra. Revisando La Grande Peur dans la montagne para essa nova edição, Ramuz, de fato, suprimiu os quatro últimos parágrafos da edição original ${ }^{11}$. De certa forma, o "desligamento coletivo", a separação dos seres, é resolvida pela morte. Os dois clãs são agora apenas um...

O fim da edição original conserva uma relação mais interessante na problemática das lendas. Os quatro últimos parágrafos mostram que a narrativa dos eventos foi transmitida, oralmente, por alguns raros sobreviventes anônimos e por turistas - uma forma de distanciar a catástrofe, ao situála em um passado distante e nebuloso, um passado lendário cujas evidências se diluem.

No parágrafo que se segue à enumeração dos mortos, os raros sobreviventes dão seus testemunhos:

Oh! dizem eles, todos que estiveram lá em cima, do primeiro ao último, de uma forma ou de outra; sem contar que passamos lá depois deles... Não se pode contar todos os mortos do vilarejo, porque sobreveio uma gripe terrível: e, enquanto os animais morriam na palha, nós, era em nossas camas..."

O "nós" e o "on" não se podem referir de maneira absoluta a nenhum dos personagens do romance. Já que as principais testemunhas estão mortas ou desaparecidas, restam somente sobreviventes anônimos para narrar os fatos.

$\mathrm{O}$ parágrafo seguinte acentua ainda mais o distanciamento da catástrofe. As notícias vindas do pasto chegaram

\footnotetext{
${ }^{11}$ As supressões são relativamente comuns em Ramuz, que tinha o hábito de condensar o tex to quando os revia. Ver o livro de Gilbert Guisan sobre a função das variantes na obra de Ramuz (Ramuz ou le génie de la patience. Genebra: Droz, 1958).
} 
"mais tarde" por intermédio de "forasteiros". Decididamente, a história que acabava de ser contada já tinha circulado muito. Alguém a conhecia por meio de outra pessoa, que antes dela...

O penúltimo parágrafo informa que a pastagem já não existe mais: "tudo tinha sido recoberto pelas pedras". Daquela maldita parte alta não há mais nem testemunhas (os pastores morreram ou desapareceram), nem vestígios. Só permanece a narrativa, uma antiga lenda.

Em outras palavras, o último parágrafo "soa" como uma lenda e parece saído da voz dos anciãos que "antropomorfizam" a montanha:

E nunca mais, desde aquele tempo, ouviu-se lá no alto o barulho das sinetas dos animais; é que a montanha tem suas próprias idéias, é que a montanha tem suas vontades.

\section{O poder do contador}

A edição original dá assim a última palavra não mais à morte, como no texto das CEurres complètes, mas à lenda; uma lenda que sobreviveu à catástrofe; uma lenda que de certa maneira transcende a morte dos habitantes do vilarejo.

Nessa perspectiva, La Grande Peur dans la montagne (1926) se inscreve no prolongamento de Passage du poète (1923) e de L'Amour du monde (1925), dois romances de Ramuz que destacam os poderes da narrativa, da "palavra que circula".

Besson, o poeta-artesão de Passage du poète, permite a uma pequena comunidade vinícola ter acesso à palavra. Antes desunidos, separados e mudos, os habitantes se reúnem por ocasião de uma festa de tiro, pontuada por inúmeros discursos muito escutados e aplaudidos. Besson pode então partir novamente: "Ele já não é mais necessário. Aprenderam a falar, todos sabem falar; ele se cala"*. A palavra, aqui o discurso, circula e abole a separação entre os seres.

Em L'Amour du monde, Joël faz com que seus companheiros de bar viajem com ele graças às suas narrativas. A imaginação leva os ouvintes para além de seus espaços lacustres:
"(: 185.)
" "On n'a plus besoin de lui. Ils ont appris à parler, ils savent tous parler; lui se dinand. OEuvres complètes, vol. 11. Ob. cit.: 256 .) 
(Ramuz, Charles-Ferdinand. CEuvres complètes, vol. 13. Ob. cit.: 66.)

(Ramuz Charles-Ferdinand. La Grande Peur dans la mon tagne. Ob. cit.: 49.)
Víamos passar nas águas, dentro das pirogas, homens de uma outra cor, sob velas de outro formato. Víamos a fumaça da Dent d'Oche.

Chautemps já não sabia mais muito bem onde estava $[\ldots] .{ }^{*}$
On voyait passer sur les eaux, dans leur pirogues, des hommes d'une autre couleur de peau, sous des voiles d'une autre forme. On voyait fumer la Dent d'Oche.

Déjà Chautemps ne savait plus très bien où il était $[\ldots]^{*}$

Em La Grande Peur dans la montagne, encontra-se igualmente uma cena que ilustra o poder do contador. Em uma das primeiras noites no chalé da montanha, o velho Barthélemy narra o que tinha acontecido vinte anos antes naquele mesmo lugar. Evoca os acontecimentos depois dos quais a pastagem passou a ser considerada maldita. Naquela noite o ambiente ficou pesado. O entusiasmo do início tinha desaparecido, já era alta noite e ouviam-se barulhos no teto. Foi então que Barthélemy começou sua história. Um verdadeiro modelo de história de terror, com crescimento e suspense. Ele pesa bem suas palavras, brinca com os silêncios e chega a provocar o medo nos companheiros. A narração sublinha os gestos do orador e dá amplitude a seus movimentos. O início da narrativa diz assim:

Disse ele:

"É porque eu estava lá."

Sua imagem parecia maior, toda sua pessoa como que crescia: retirou-se para o fundo.

A luz foi diminuindo até não mais existir, ao mesmo tempo em que as sombras pareciam entrar outra vez nos objetos que as tinham criado: não havia mais nada senão as sombras, e em meio a elas: "Sim... eu estava lá."*
Il a dit: "C'est que j’y étais."

Sa figure parut grandir, toute sa personne grandissait: elle fut retirée en arrière.

Le fond de la lumière a été diminué jusqu'à n'être plus du tout, tandis que les ombres sont rentrées dans les objets qui les avaient portées dehors: il n'y a plus eu que l'ombre, et c'est dans l'ombre: "Oui... j’y étais."

Quando a história chegar ao fim, os seis pastores estarão mudos, imobilizados pela narrativa de Barthélemy. Mesmo os mais céticos parecem então invadidos pela dúvida. Ficarão todos, a partir de então, unidos pelo medo, com exceção do diabólico Clou.

"Tudo depende do lugar e do meio", diz o narrador de Horla, que prossegue: "Crer no sobrenatural na Ilha da 
Grenouillère seria o cúmulo da loucura... mas no alto do monte Saint-Michel? ... mas e nas Índias?"*. "Mas e nas altas montanhas de Sasseneire ao pé das geleiras?", poderíamos do mesmo modo acrescentar. Essa história da pastagem maldita parecia pouco importante no vilarejo lá embaixo. Mas lá em cima tudo era muito diferente!

A narrativa de Barthélemy e o contexto em que ela se produziu fazem pensar nas vigílias em que se contavam as lendas. Enquanto todo mundo está reunido em volta do fogo, um velho toma a palavra e evoca uma história dos tempos idos.

Ramuz foi buscar nas lendas não apenas uma simbologia, tipos de personagens e situações, como também uma maneira de contar. A lenda exige uma enunciação particular em que Ramuz se pôde inspirar. Sobre isso, devo dar a palavra a Philippe Renaud. Em um belíssimo ensaio intitulado Ramuz ou l'intensité d'en bas, o autor estabelece uma analogia entre as vigílias e as narrativas ramuzianas:

Nas histórias de vigília, as vozes são múltiplas. Há relações várias entre o illud tempus e os membros do círculo familiar alargado, do círculo dos amigos e conhecidos: "a gente" sabe (ou finge saber) que "a gente" (tal ou qual antepassado) viu ou contou isto ou aquilo. Daí evidentes mudanças de ponto de vista que deixam entre elas alguns "vazios". Salta-se de uma geração (a) a outra (c) ou (d) como se saltaria de um mais-que-perfeito precedido de um "depois que" a um presente, que é o tempo do primo mais jovem. As opiniões divergem, os pontos de vista espaçotemporais e também as ideologias se entrecruzam sem nunca se homogeneizarem. A morte prematura de um pai corresponde a uma lacuna temporal.

Se esta hipótese é válida, ela está bem longe de poder explicar tudo: nem por isso ela deixa de representar um modelo e sobretudo uma forma. De fato, durante a vigília, se há discordância sobre algum conteúdo, o que importa mesmo é a manifestação, graças à história, da harmonia ou do conflito do grupo familiar, alargado ou não. Fica evidente que reina aí uma atitude de locução comentativa. Qualquer coisa pode servir para narrar o "verdadeiro". O pronome "on", aqui, pode fazer maravilhas: "on", não sendo ninguém, é, no entanto, entendido como pronome da garantia. Os tempos se embaralham, muitas vozes se sucedem ou se contradizem; quando "on" não sabe, "on" imagina e diz: " on’ poderia tê-lo visto se tivesse havido alguém” etc. Inútil se prolongar sobre a evidência de que se atribuirá sempre a um tetravô (morto há muito tempo) o conhecimento definitivo dos fatos."

" "Croire au surnaturel dans l'île de la Grenouillère, se. rait le comble de la folie... mais au sommet du mon Saint-Michel?... mais dans les Indes?" (Maupassant,
"(Renaud, Philippe. Ramuz ou l'intensité d'en bas. Lau sanne: L'Aire, 1986: 98.9.) 
Para Ramuz, a lenda é um dos modelos da palavra que passa, circula e une uma comunidade em torno de um contador, um poeta. Graças ao verbo, um orador pode levar para longe os que o escutam. A narrativa age por meio de uma emoção que ganha e une progressivamente os ouvintes: o sonho, em L'Amour du monde, a euforia e a felicidade, em Passage $d u$ poète, e o medo, em La Grande Peur dans la montagne. Medo que se propaga em círculos concêntricos, invadindo primeiramente os pastores, depois os habitantes do vilarejo e, finalmente, os leitores.

E se "tudo depende do lugar e do meio", como sublinha o narrador de Horla, só se pode recomendar que se leia La Grande Peur dans la montagne à noite, sozinho, e em um lugar isolado. De preferência, na montanha!

Tradução: Daniela Cerdeira da Silva 


\section{Jérôme Berney}

Formado em Letras, colaborou na edição dos romances de Ramuz pela Bibliothèque de la Pléiade entre 2001 e 2003. Em especial, co-dirigiu um número de Etudes de Lettres dedicado ao autor ("No ateliê de Ramuz”, n. 1-2, 2003). Atualmente, ensina francês e literatura em estabelecimento secundário superior.

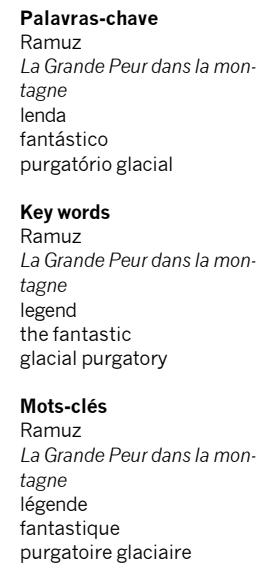

Recebido em $31 / 10 / 2003$

Aprovado em 15/03/2004

\section{Resumo}

Ramuz era apaixonado pelas lendas alpinas e nelas se inspirou para escrever numerosos textos. O presente artigo examina o caso de $L a$ Grande Peur dans la montagne, de 1926, e mostra que o romance é atravessado por vários lugares comuns lendários, como o caçador diabólico e o purgatório glacial onde erram as almas danadas. À maneira de certas novelas de Maupassant, o personagem principal de La Grande Peur, Joseph, confronta-se com acontecimentos sobrenaturais que o fazem progressivamente penetrar em um universo onírico, fantástico, até mesmo fantasmático. O final do romance, ao menos na edição original, permite pensar que a narrativa como um todo é uma lenda.

\section{Résumé}

Ramuz s'est passionné pour les légendes alpines et il s'en est inspiré dans de nombreux textes. Cet article examine le cas de $\mathrm{L} a$ Grande Peur dans la montagne (1926), en montrant que le roman est traversé par plusieurs lieux communs légendaires, comme le chasseur diabolique et le purgatoire glaciaire où errent les âmes des damnés. A l'instar de certaines nouvelles de Maupassant, le personnage principal de La Grande Peur, Joseph, est confronté à des événements surnaturels quile font progressivement dériver dans un univers onirique, fantastique, voire fantasmatique. Par ailleurs, la fin du roman, du moins dans l'édition originale, peut laisser penser que l'ensemble du récit est une légende. 